\title{
Global village dan Globalisasi dalam Konteks ke-Indonesiaan
}

\author{
Cahyo Pamungkas
}

Lembaga Ilmu Pengetahuan Indonesia (LIPI)

\begin{abstract}
ABSTRAK
Tulisan ini memunculkan definisi global village dalam konteks Indonesia. Bagian pertama dari makalah ini menjelaskan konsep awal global village oleh McLuhan (1962) yang terkait dengan keterhubungan antarwarga dunia. Bagian kedua menerangkan respon terhadap konsep global village dan bagian bagian ketiga menjelaskan perbedaan antara global village dan globalisasi. Akhirnya, penelitian ini menggambarkan global village dan globalisasi dalam konteks Indonesia. Global village dapat didefinisikan sebagai fenomena globalisasi pada masa kini yang dapat dikenali dari akibatnya yakni melemahnya batas-batas nasional, menghilang identitas dan budaya lokal, mengancam ekonomi nasional di tengah-tengah ekspansi modal, dan meningkatnya migrasi internasional. Konsep ini mengacu pada spektrum masyarakat baru yang melampaui batas-batas geografis, ekonomi, politik dan budaya dan menekankan pada arus informasi dalam jaringan komunikasi.
\end{abstract}

Kata-Kata Kunci: Global village, Globaliasi, dunia tanpa batas.

This paper is addressed to explore the concept of global village related to the current globalization phenomena. Based on that concept, this article comes up with a definition of global village in Indonesian context. The first part of this paper describes the early concept of global village by McLuhan (1962) that related to connectedness among world citizens. The second part sheds light on respons to global village and the third part explains differences between global village and globalization. Finally, this study illustrates global village and globalization in Indonesian context. Global village in this study can be defined as the current globalization phenomena recognized by its effect on weakening national boundaries, disappearing local identity and culture, threatening national economic in the midst of capital expansion, and rising international migration. This concept refers to a spectrum of new society that beyond geographical, economic, political and cultural boundaries and emphasize on information flow in the network of communication.

Keywords: Global village, Globalization, Borderless World. 
Tulisan ini dimaksudkan untuk memberikan pemahaman secara konseptual terhadap istilah global village berdasarkan hasil studi literatur dan temuan-temuan hasil diskusi dengan para peneliti ilmu sosial di Indonesia dan di luar negeri. Pertanyaan yang ingin dijawab oleh tulisan ini adalah (i) apakah pengertian global village menurut studi literatur? (ii) Apakah perbedaan makna antara global village dan globalisasi, (iii) bagaimanakah makna global village dan globalisasi dalam konteks Indonesia, dan (iv) bagaimanakah makna global village berdasarkan sintesis antara studi literatur, konteks Indonesia dan konteks global. Konsep global village pada awalnya lebih banyak digunakan oleh para peneliti bidang media dan komunikasi untuk menggambarkan suatu evolusi perkembangan pola interaksi masyarakat yang dipengaruhi oleh perkembangan teknologi. Merujuk pada McLuhan (1962), konsep ini mendeskripsikan bagaimana perkembangan media-media elektronik mengakibatkan hilangnya kendala-kendala/batas-batas ruang dan waktu dalam komunikasi antarmanusia. Selanjutnya hal ini mendorong masyarakat untuk berinteraksi secara intens dan tinggal dalam sebuah ruang global. Pada tataran teoretik, terminologi global village seringkali berkelindan dengan konsep globalisasi yang melihat objek yang sama, yakni integrasi masyarakat secara sosio-ekonomi dan sosio-kultural. Oleh karena itu, tulisan ini bermaksud untuk menelusuri konsep global village dan globalisasi. Pada bagian terakhir, konsep global village akan dirumuskan dalam konteks fenomena globalisasi yang sedang terjadi di Indonesia pada masa kini.

\section{Pemikiran Mcluhan tentang Global village}

McLuhan (1962) dalam bukunya yang berjudul Guttenberg Galaxy, menjelaskan bahwa fenomena saling ketergantungan secara elektronik, yang belum pernah terjadi sebelumnya, telah menciptakan kembali dunia dalam sebuah imajinasi tentang desa besar (global village). Pandangan ini didasari oleh salah satu pandangannya bahwa perkembangan teknologi dalam media massa elektronik secara luas pada tahun 1950an, seperti radio dan televisi, telah menyebabkan semakin mudahnya aliran informasi ke segala penjuru dunia. Salah satu dampak dari perkembangan media terutama di negara-negara Barat pada masa tersebut adalah munculnya oral society, suatu masyarakat dimana saling ketergantungan antara unsur-unsur yang membentuknya merupakan hasil dari dialektika antara penyebab dan akibat dari dinamika di dalam struktur masyarakat yang saling berinteraksi. Karakteristik tersebut dianggap sebagai sifat dasar dari sebuah masyarakat desa, yang juga menjadi sifat dasar sebuah masyarakat desa global (McLuhan 1962, 26). Komunitas hubungan masyarakat (public relation) dan periklanan merupakan salah satu unsur masyarakat yang 
paling sadar terhadap dimensi ketergantungan global ini dimana mereka sangat memperhatikan akses terhadap media dan pengaruh media terhadap masyarakat.

Pada bagian lain McLuhan (1962, 36) memaparkan dampak lain dari perkembangan teknologi media, yakni masyarakat manusia (human society) pada masa kini tinggal dan hidup di bawah lingkup global village. Berikut metafor yang dipakai oleh McLuhan $(1962,36)$ untuk menjelaskan konsep Global village: "We live in a single constructed space resonance with tribal drums." Metafor tersebut didasarkan atas penemuan-penemuan teknologi elektromagnetik yang telah menciptakan sektor-sektor atau bidang-bidang baru dalam keseluruhan permasalahan yang dihadapi manusia, yang berkaitan satu sama lain. Sebagai konsekuensinya, kita semua tinggal dalam satu ruangan tunggal dimana ruang-ruang kehidupan sosial saling tumpang tindih satu sama lain. Pada dasarnya, McLuhan ingin menyampaikan bahwa perkembangan teknologi telah mempengaruhi keseluruhan masyarakat di mana mereka hidup dalam imajinasi ruangan bersama, yang diumpamakan sebagai sebuah desa global (global village).

Dalam karyanya yang lain, Understanding Media, McLuhan (1994) memusatkan perhatiannya pada perkembangan teknologi komunikasi yang mencakup baik negara-negara maju maupun negara-negara berkembang. Menurutnya, setelah ditemukannya telegrap, pesan (messages) dapat sampai lebih cepat daripada petugas pos. Sebelumnya, dunia tulisan memiliki hubungan yang sangat dekat dengan jalan raya. Namun, setelah penemuan telegrap, informasi (pesan) tidak terikat lagi pada komoditas seperti batu dan kertas papyrus, sebagaimana uang tidak terikat lagi dengan logam dan berakhir menjadi kertas (McLuhan 1994). Perkembangan teknologi komunikasi seperti ini, dimana pesan berubah menjadi medium itu sendiri, mendorong evolusi peradaban manusia lebih jauh dibanding pada masa-masa sebelumnya.

Mengutip Arnold Tonybee, McLuhan (1964) mengatakan bahwa evolusi perkembangan masyarakat akibat perkembangan teknologi komunikasi dan informasi ditandai oleh proses disintegrasi dan penundaan (reprieve). Kedua proses ini memfasilitasi evolusi peradaban manusia melalui penyatuan politik dalam sebuah negara yang bersifat universal. Dengan kata lain, evolusi masyarakat dunia akan bermuara pada proses penyeragaman dan penyatuan baik secara ekonomi, sosio-kultural, dan politik. Proses pembentukan imajinasi global village seperti ini distimuli oleh fenomena yang disebut sebagai pergerakan cepat (speed up). Fenomena ini mendorong pembentukan pusat-pusat kekuasaan (center) dan daerah-daerah pinggiran (margin) $(1964,104)$. Ketika pergerakan cepat ini berlangsung, perkembangan teknologi menciptakan independensi 'desa-desa' dan 'negara-negara kota', pusat-pusat 
kekuasaan yang baru tumbuh selalu mengambil tindakan untuk menyeragamkan sebanyak mungkin daerah-daerah marjinal disekitarnya.

Konsekuensi logis dari proses perkembangan teknologi informasi dan komunikasi yang sangat cepat, menurut McLuhan (1994), adalah munculnya proses-proses sosial yang disebut dengan de-westernisasi (akulturasi budaya Barat dengan budaya lain) yang menimpa orangorang Barat yang telah mengunjungi dunia timur dan de-tribalisasi (berubahnya nilai-nilai budaya lokal menjadi modern) oleh orang-orang Afrika yang telah mengenal teknologi informasi dan industri dari negara-negara Barat. Fenomena pertama terjadi ketika orang-orang Barat mempelajari dan mengadopsi nilai-nilai dan norma-norma di dunia Timur, sedangkan fenomena kedua terjadi ketika orang-orang Afrika meggunakan teknologi modern untuk menyelesaikan permasalahan yang dihadapinya dalam kehidupan sehari-hari sebagaimana yang terjadi di dunia Barat. Kedua proses sosial ini ditandai oleh kegiatan-kegiatan spesialisasi dan pemisahan (specialization and separation) yang merupakan sifat dasar terbentuknya masyarakat modern yakni pembagian masyarakat menjadi kelompok-kelompok yang bersifat spesifik (social differentiation) seperti digambarkan oleh Durkheim (Parson 1967).

Bila ditelusuri lebih jauh, evolusi pembentukan global village bukanlah hal yang baru tetapi berawal pada masa Romawi. Fenomena pergerakan informasi yang cepat seperti telah dijelaskan di muka dapat ditemukan oleh penggunaan teknologi roda, jalan raya, dan kertas sebagai medium komunikasi antarwarga masyarakat atau kelompok masyarakat. Perkembangan teknologi transportasi pada masa tersebut dan masamasa sesudahnya menunjukkan fenomena perluasan kekuasaan dan membuat masyarakat dunia menjadi lebih homogen dan memaksakan terciptanya ruangan hidup yang lebih homogen. Bahkan, McLuhan (1994, pp. 106) menunjukkan bahwa bagi masyarakat yang tinggal di dunia Barat, pada masa kini, menganggap bahwa abad perkembangan teknologi merupakan sebuah fenomena yang mengganggu (disrupt) pengetahuan (literate), keturunan (lineal), dan manusia Barat (Western man). Sebenarnya fenomena global village berkaitan erat dengan konsep McLuhan yang lain yakni global theatre yang menjelaskan dinamika di dalam global village. Namun, studi ini tidak akan memasukkan konsep tersebut menjadi salah satu pokok bahasan.

\section{Respon Terhadap Pemikiran Mcluhan}

Pemikiran McLuhan tentang global village bukanlah hal yang baru dalam bidang studi media dan komunikasi. Meskipun banyak yang 
mendukung, tetapi banyak pula kritik yang ditujukan terhadap konsep ini. Misalnya, Chrystal (2011) mengelaborasi pemikiran-pemikiran yang bersifat kritis terhadap konteks global village, seperti argumen Dery (1995) yang menjelaskan bahwa global village adalah visi yang utopis. McLuhan menggunakan terminologi global village untuk menerangkan evolusi landscape media pada akhir abad ke-20. Selain Dery, Huysen (1995) juga mengatakan bahwa konsepsi global village McLuhan menyerupai teologi media yang dapat dijelaskan jika kita mengganti konsep roh kudus untuk menyebut fenomena listrik (electricity), tuhan untuk medium komunikasi, planet yang bersatu di bawah Roma (Kekristenan) untuk global village.

Kritikus yang lain, Facwett (2004), mengatakan bahwa konsep global village McLuhan relevan untuk menganalisis perkembangan televisi tetapi secara berlebihan terhadap perkembangan video sebagai alat pedagogis bagi media literacy. Juga konsep global village cenderung mengabaikan kritik terhadap dampak negatif globaliasi dan tidak memperhatikan hal-hal yangterkait dengan distribusi kapital internasional. Seorang kritikus lain, Schafer (1993), mengungkapkan bahwa global village sebagai sebuah realitas belum terwujud sepenuhnya karena apa yang disebut sebagai akses terhadap internet (digital natives) belum sepenuhnya merata. Schafer sependapat dengan McLuhan bahwa kita semua hidup di dalam dunia global elektronik tetapi bukan menyatu ke dalam sebuah ruang global yang disebut sebagai desa. Konsep village berimplikasi secara teoretik pada sebuah pemukiman kelompok manusia dimana orang-orang berinteraksi satu sama lain.

Pandangan lain diberikan oleh Trednick (2008) yang menyebutkan bahwa konsep global village McLuhan dalam perspektif ilmu sosial tidak bisa disejajarkan dengan konsep post-industrial society (Bell), post-modern condition (Lyotard), the end of history (Fukuyama), network society (Castel). Konsep global village hanyalah tipe ideal, sedangkan Konsep-konsep tersebut sudah dianggap menjadi narasi (teori) besar dalam ilmu sosial. Namun demikian, global village adalah sebuah pengamatan empiris terhadap situasi yang terjadi pada tahun 1950-an. Analisis Chrystall terhadap fenomena global villagemenunjukkan bahwa semakin banyak proses globaliasi menciptakan karakter village, dalam arti penyeragaman, semakin banyak perbedaan dan konflik pada satu sisi; dan keseragaman pada sisi lain.

Global village masih mengandung sifat primitif di mana kontestasi politik, ekonomi, dan kultural jauh lebih keras dibandingkan dengan pada masa perkembangan nasionalisme. Pada tingkatan tertentu, global village digunakan untuk mengekspresikan sebuah imajinasi yang 
muncul dari tekanan terhadap komunitas global yang tiada henti. Imajinasi ini dapat diwujudkan melalui terbentuknya kota-kota global sebagai pusat dari daerah-daerah marjinal. Secara konseptual, global village juga digunakan untuk melakukan diagnosa terhadap perkembangan media dan komunikasi kontemporer. Selain itu global village juga dapat dilihat dari dampaknya terhadap identitas diri dimana jati diri menjadi tidak dapat dikenali lagi dan bukan sebuah entitas tunggal (Christall, pp. 21).

Kritik terhadap konsep global village McLuhan juga dilakukan oleh Jackson (2010).Yang menafsirkan kembali konsep global village McLuhan sebagai suatu perkembangan teknologi transportasi (jalan, mobil, kereta, pesawat terbang, kapal), teknologi informasi (buku, radio, dan televisi), dan internet membuat pesan maupun orang dapat berpindah dengan sangat cepat baik secara fisik maupun persepsi. Ketika fenomena ini terjadi, hubungan manusia dalam lingkup geografis menjadi tidak jelas dan akibatnya muncullah suatu budaya yang merupakan karakter desa. Menurut Jackson, McLuhan berusaha untuk menjelaskan bagaimana teknologi informasi dan komunikasi mempengaruhi interaksi manusia, persepsi, dan perubahan budaya.

Global village mengakomodasi filsafat asimilasionis, sebuah pandangan filsafat dan paradigma pemikiran yang menerima satu atau sedikit ideide kebudayaan, mendorong orang untuk melekat atau setia pada sekelompok nilai yang dominan. Dengan demikian, perbedaanperbedaan antarbudaya dan individu menjadi terhapus atau memudar. Sebagai contohnya adalah upaya untuk menjadikan bahasa Inggris sebagai bahasa utama, sementara bahasa negaranya sendiri menjadi bahasa nomor dua. Pandangan ini dapat terwujud jika didukung oleh teknologi informasi dan komunikasi seperti televisi, film, dan internet. Perkembangan teknologi informasi, komunikasi, dan transportasi menyebabkan masyarakat menjadi semakin terbuka untuk mempelajari hal-hal inovatif yang datang dari luar. Sebagai akibatnya ketika batasbatas kebudayaan secara fisik dan persepsi memudar, pandanganpandangan budaya dan nilai-nilai yang bersifat spesifik menjadi ikut menghilang. Warisan local (local heritage), ikatan-ikatan persaudaraan, dan tradisi-tradisi yang unik menjadi terlupakan atau menghilang secara gradual dari waktu ke waktu. Dengan demikian, filsafat liberationist menjadi semakin sulit untuk diwujudkan.

Paradigma liberationis mengijinkan seseorang atau sekelompok masyarakat untuk memercayai banyak kebenaran, pandangan, dan nilainilai kebudayaan yang berbeda-beda dan pada tingkat-an tertentu saling bertentangan. Munculnya fenomena global village membuat orangorang semakin mudah untuk bertemu dan berkumpul bersama, mentransformasikan perbedaan, dan mengembangkan seperangkat nilai 
dan pandangan yang dominan. Bangsa-bangsa dan masyarakat di berbagai belahan dunia dapat memutuskan untuk mengubah pandangan budaya dan nilai menuju seperangkat nilai yang dianggap lebih baik. Contohnya, demokrasi sebagai tata pemerintahan yang ideal, kapitalisme sebagai tatanan ekonomi yang ideal, Kristen sebagai agama yang ideal, dll. Kebudayaan-kebudayaan tertentu dalam global village dianggap sebagai tidak layak, kurang beradab, dan tidak pantas (circumcision, hunting wheels, arranged married, dll).

Fenomena global village itu dapat diamati pada beberapa realitas sebagai berikut. Hubungan virtual yang semakin meningkat dimana interaksi langsung tatap muka berubah menjadi interaksi virtual melalui internet. Ketika interaksi tatap muka menjadi kurang frekuensinya dilakukan oleh masyarakat, muncul mekanisme pasar untuk mengisi kekosongan ruang-ruang ini seperti bisnis kafe yang dilakukan oleh Starbuck. Fenomena global village juga didukung oleh semakin berkembangnya teknologi satelit dan GPS (global positioning system). Teknologi ini menyebabkan memudarnya disiplin ilmu yang berbasis pada geografis dan ruang material (anthropology, sociology, geography). Ilmu-ilmu tersebut didefinisikan kembali terutama berkaitan dengan terminologi globalisasi, postkolonialitas, transnational, diaspora, dan studi indigenous people.

Studi lain tentang global village dilakukan oleh Alterand Kwan yang dimuat dalam Journal of Personality and Social Psychology(2009). Kwan menekankan konsep global village pada cultural sharing. Penelitian Kwan menjelaskan bahwa masyarakat Amerika Serikat dihadapkan pada keragaman budaya yang berpotensi mempengaruhi penilaian dan perilaku mereka. Meskipun banyak perbedaan antara budaya tetap ada, namun studi ini menyarankan bahwa kesadaran masyarakat terhadap kepercayaan dan budaya yang berasal dari luar negaranya semakin meningkat. Sebagai konsekuensinya, menurutnya, dunia tidak mungkin terdiri dari hanya satu global village saja, tetapi terdiri dari berbagai komunitas dunia yang mampu menjembatani perbedaan yang eksis (Kwan 2009). Secara umum dapat disimpulkan dari studi Kwan bahwa perkembangan teknologi media dan informasi tidak cenderung membentuk satu komunitas global village yang bersifat tunggal. Hal ini disebabkan oleh meningkatnya kesadaran untuk menghormati budaya yang lain. Pandangan ini bertentangan dengan konsep global village McLuhan yang menekankan terbentuknya satu masyarakat global yang disebut dengan global village.

Secara mendasar juga diyakini bahwa konsep global village mengidap ketidakimbangan (imbalances), dengan sebuah penekanan yang amat positif terhadap fenomena global sebagai hal yang tidak terhindarkan dan patut terjadi bagi perkembangan peradaban manusia. Dalam sisi ini, 
konsep global village nampak melihat bahwa menyatunya masyarakat dunia dalam sebuah ikatan ataupun jaringan media dan komunikasi mondial sebagai sesuatu yang memberikan banyak keuntungan. Bayangan akan adanya "kampung besar" dengan sebuah "single constructed space" mengindikasikan adanya situasi yang berkonotasi harmoni, guyub, yang dilandasi sebuah semangat berhubungan saling menguntungkan.

Pemaknaan kampung itu sendiri pada akhirnya dirasakan sebagai sesuatu mengisyaratkan adanya sebuah utopia, jika dimaknai secara literar. Pada kenyataannya dalam membangun komunikasi dengan kalangan yang berbeda negara memang amat mungkin untuk dilakukan, namun mendapatkan kepercayaan dan rasa persaudaraan layaknya sesorang yang tinggal sekampung tidaklah mudah untuk diperoleh atau dibangun. Begitupula adanya perasaan "at home" tidaklah mudah tercipta begitu saja manakala sesorang tinggal di sebuah wilayah yang jauh dari tempat ia dibesarkan atau dilahirkan. Tetap saja ada khalayan dan perasaan berbeda atau yang khas yang tidak dapat mudah ditumbuhkan di sebuah tempat yang dia tidak familiar atau terikat secara budaya setempat.

Apalagi dewasa ini kenyataan yang justru terjadi kerap bertentangan dengan idealisme sebuah kampung global. Persaingan atau bahkan pertentangan sering terjadi di wilayah-wilayah negara yang saling berdekatan. Contoh terakhir adalah apa yang terjadi di Ukraina, Irak, Suriah ataupun Nigeria, di mana masyarakat atau kelompok-kelompok masyarakat yang bahkan tinggal berdekatan saling bersaing dan berkonflik menunjukan identitas khasnya dan kepentingan yang saling kontradiktif.

Kalangan kritis melihat konsep global village sebagai media pembenaran atau alat legitimasi bagi pertumbuhan dan gerak ide-ide Barat yang cukup massif termasuk demokrasi dan kapital-isme global. Konsep ini dipandang tidak kritis terhadap ekses-ekses yang ditimbulkan dari transfer nilai-nilai Barat dan perkembangan global, yang tentu saja tidak semuanya memberikan dampak yang menguntungkan bagi umat manusia. Pembagian kelas dan situasi global yang menciptakan "kelas-kelas negara" sebagaimana yang dibayangkan oleh Wallerstein, misalnya, pada kenyataannya tidak dapat terjembatani dengan tetap memberikan keuntungan yang maksimal bagi segelintir negara saja. Di sisi lain, "penjajahan" ide dan sistem Barat menjadi ekses lain yang tentu saja menimbulkan kegelisahan di negara-negara nonBarat.

Situasi ini dalam batas-batas terjadi lantaran konsep ini dibangun dalam kurun waktu ketika proyek modernitas atau modernisasi tengah 
mendapatkan momentumnya. Dalam pandangan modernitas ini, secara mendasar dibayangkan bahwa masyarakat di berbagai belahan dunia akan bertransformasi dari sebuah kondisi tradisional atau terbelakang menuju kondisi yang semain modern atau unggul, dimana nilai-nilai Barat kerap menjadi patokannya karena dianggap ideal. Meski konsep ini mengisyaratkan adanya situasi saling ketergantungan, namun konsep kampung yang dibayangkan pada akhirnya tetap memiliki patokanpatokan yang sulit untuk tidak dikatakan mengadopsi nilai-nilai ideal Barat.

Dalam kerangka berfikir ini, konsep ini secara sepihak mengandaikan bahwa dampak positif akan muncul dengan sendirinya manakala nilainilai Barat dapat berkembang secara masih ke seluruh penjuru dunia melalui sokongan teknologi atau jaringan komunikasi yang masif. Sementara itu, di sisi lain, kalangan negara-negara non-Barat, akan banyak terbantu dan tercerahkan dengan adanya ikatan yang membawanya lebih dekat dengan cara pandang luhur Barat. Di sini, cara pandang positivisme, yang menjadi salah satu sokoguru konsep-konsep yang berintikan modernisasi, yang bersifat linier terlihat demikian dominan dalam konsep ini.

\section{Global village Dan Globalisasi}

Bagian ini memaparkan perbedaan konseptual antara global village dengan gobalisasi yang seringkali tumpang tindih. Perbedaan antara kedua konsep ini menjadi perhatian Walkasz dkk (2008). Menurut mereka, global village merupakan metafor yang digunakan untuk menggambarkan dunia yang terhubung secara elektronik dan bersifat kompleks sebagaimana prediksi McLuhan. Konsep ini dapat digunakan sebagai kerangka konseptual untuk membantu kita dalam melakukan analisa hubungan kita (masyarakat) dengan media pada masa kini dan menyiapkan masa depan. Globalisasi terhadap media, yang ditandai oleh internasionalisasi program-program TV, akses internet yang meluas, teknologi telepon genggam, telah menghubungkan dunia.

Pada sisi lain, globalisasi adalah sebuah fenomena yang melibatkan proses-proses sosial integrasi eonomi, budaya, kebijakan-kebijakan negara, dan pergerakan politik di seluruh dunia. Menurut Appadurai (2006), globalisasi merujuk pada keseluruhan proses-proses sosial yang melibatkan perpindahan orang, komoditas (barang), kapital, pengetahuan, pemikiran, informasi, dari satu negara ke negara lain. Kajian mengenai global village tidak dapat dipisahkan dari globalisasi. Konsep global village dalam terminologi studi globalisasi seringkali disebut sebagai globality. Globalisasi tidak hanya terbatas melalui media tetapi proses-proses politik dan ekonomi, serta berkaitan dengan relasi 
dominasi dan hegemoni. Sementara globality atau global village merujuk pada fenomena global saling ketergantungan yang merupakan hasil dari proses globalisasi.

Globalisasi sebagai sebuah konsep diyakini telah dibincangkan substansinya sejak abad kesembilan belas atau awal abad kedua puluh. Menurut Held dan McGrew (2004) asumsi bahwa modernitas mengikat dunia telah menelurkan banyak karya akademis yang dilakukan oleh beberapa intelektual besar seperti Saint Simon, Karl Marx hingga yang relatif lebih kontemporer seperti MacKinder. Namun demikian, sebagai sebuah konsep akademis yang lebih utuh, glbalisasi, baru benar-benar disebutkan secara gamblang dan digunakan oleh para akademisi untuk memotret fenomena dunia kekinian pada paruh kedua abad ke-20, tepatnya sekitar dekade 1960an sampai 1970an,

Kemunculan konsep tersebut seiring dengan kebutuhan yang mendesak untuk mendapatkan sebuah konsep baru yang lebih tepat dalam membahas perkembangan dunia politik, ekonomi, sosial, budaya, yang tidak dapat lagi dijawab oleh pendekatan-pendekatan lama atau ortodoks, mengingat semakin terintegrasinya masyarakat dalam sebuah ikatan yang makin mengglobal. Fenomena yang sebenarnya juga telah menemukan prototypenya sejak masa lalu, termasuk pada masa kolonial atau ditemukannya jalur sutra. Para akademisi melihat bahwa adanya sebuah situasi eksternal, khususnya kondisi saling mempengaruhi, yang tidak lagi dapat dinafikan atau diabaikan manakala mengkaji atau menganalisis sebuah perkembangan di sebuah negara atau antar negara. Jatuhnya komunisme, di awal tahun 1990an, yang disusul dengan semakin meluasnya ide demokrasi dan pasar bebas, seiring dengan semakin canggihnya perkembangan teknologi informasi, dirasakan telah makin meletakkan masyarakat dunia pada sebuah kondisi dunia yang semakin terbebas dari batasan-batasan yang menghalangi untuk munculnya sebuah hubungan yang semakin intens dan saling mempengaruhi.

Sejauh ini beragam pemahaman dan definisi mengenai globalisasi telah dihadirkan oleh banyak akademisi. Setidaknya hingga awal abad ke-21, globalisasi yang digambarkan oleh pemahaman dan definisi dari berbagai ahli globalisasi itu adalah sebuah konsep yang merujuk pada beberapa situasi atau kondisi yakni: (1) action at a distance, (2) timespace compression, (3) accelerating interdependence, (4) a shrinking world, (5) global integration, (6) the reordering of interregional power relations, (7) consciousness of the global condition dan (8) intensification of interregional interconnectedness (Held dan MacGrew 2004, 3) 
Secara umum salah satu definisi yang cukup baik dalam menggambarkan makna atau esensi dari globalisasi disampaikan oleh Held dan MacGrew. Menurut mereka globalisasi adalah "the expanding scale, growing magnitude, speeding up and deepening impact of interregional flows and patterns of social interaction. It refers to a shift or transformation in the scale of human social organization that links distant communities and expands the reach of power relations across the world's major regions and continents" (Held dan MacGrew 2004, 4).

Dalam perkembangannya, tentu saja tidak semua kalangan sepakat dengan istilah dan esensi dari globalisasi. Kalangan yang skeptis, misalnya, kerap bersikap kritis atau mempertanyakan istilah global dalam globalisasi, yang oleh karenanya mereka cenderung menggunakan istilah internasionalisasi saja. Tentangan terhadap globalisasi, baik istilah maupun maknanya, disadari oleh kalangan penganut globalisasi ini. Mereka menyadari bahwa istilah dan makna yang terkandung dalam istilah ini cukup kompleks. Merekapun menyadari bahwa tidak semua kalangan di belahan bumi ini mengalami level penetrasi dari globalisasi yang sama. Oleh karena itu, tidak saja keberagaman mengenai globalisasi yang terjadi, namun secara mendasar globalisasi dapat juga memberikan efek yang beragam dan dampak yang tidak selamanya positif bagi warga dunia. Terlepas dari itu ada beberapa penjelas dari konsep ini, terkait terutam dengan isu-isu besar seperti kekuasaan atau eksistensi negara-bangsa, ekonomi, budaya dan sebagainya. Salah satunya disampaikan oleh Held dan MacGrew (2004), yang menyarikannya beberapa penjelasan terkait dngan isu besar itu dari rangkuman perdebatan antara pendukung globalisasi (globalis) dan mereka yang menentangnya (skeptis).

Studi Walkas dkk. (2008) menunjukkan bahwa global village menunjukkan fenomena budaya yang bersifat global menjadi lokal dan fenomena budaya yang bersifat lokal menjadi global. Global village pada awalnya sering dipertentangkan dengan local village yang menyediakan sebuah lingkungan di mana setiap orang mengetahui satu sama lain sepanjang periode waktu tertentu di bawah kondisi-kondisi tertentu pula. Orang-orang tua dan orang-orang dewasa lainnya memfilter apa yang boleh dan tidak boleh dipelajari generasi muda yang mencakup gaya hidup, nilai-nilai, dan pandangan. Namun dewasa ini, fenomena lokal menjadi global karena perkembangan teknologi media dan informasi. Desa yang lokal sudah menjadi besar sehingga tidak diperlukan saringan-saringan moral melalui interaksi manusia karena filter yang digunakan pada masa kini adalah teknologi sebagai pengganti moral.

Konsep globalisasi, menurut Walkas dkk. (2008), sebagaimana diaplikasikan pada media, telah menghasilkan apa yang McLuhan 
prediksi tentang global village yang unsur-unsur pembentuknya saling berhubungan. Namun demikian, anggota-anggota dari desa besar ini tidaklah bersifat terhubungkan (connected) secara homogen. Akan tetapi lebih menyerupai sebuah lingkungan yang bersifat kompleks yang memiliki implikasi-implikasi politik, ekonomi dan sosial (Hobbes 2007; Krandy, 1999). Lingkungan media global mengijinkan audiensnya berbagi beberapa hal yang sama seperti program-program TV, keinginan terhadap produk yang sama, dan hal-hal yang diiklankan oleh media. Konglomerasi media global yang bersifat komersial ini menyediakan akses terhadap program tv, film, video, dll sehingga dikhawatirkan memunculkan imperialisme budaya dan menghasilkan kultur dominan. Generasi muda cenderung lebih percaya dan tergantung pada platform media daripada bimbingan orang tua mereka.

Proses globaliasi dan lokalisasi menghasilkan output yang unik di daerah-daerah tertentu seperti telah disebutkan di muka menjadi relevan dalam hal ini. Globalisasi adalah sebuah proses dimana korporasi-korporasi global memproduksi dan memasarkan produknya dalam lingkungan tertentu di tingkat lokal untuk memenuhi variasi permintaan konsumen. Konsep ini juga merupakan kerangka untuk menganalisis cara-cara dimana aktor aktor sosial mengkonstruksi makna, identitas, dan bentuk bentuk kelembagaan di dalam konteks sosiologis globalisasi (Guilanotti dan Robertson 2006).

\section{Global village Dan Globalisasi Di Indonesia}

Konsep global village McLuhan(1962) menempatkan dunia layaknya sebagai suatu desa berkat teknologi elektrik dan lalu lintas informasi yang serba cepat dan instan. Menurut Mailing Oey, pakar demografi FEUI,' inti dari global village McLuhan adalah 'the medium is the message" yang berarti bahwa global village tidak terlepas dari globalisasi yang berarti interdependensi antarnegara dan dunia semakin terintegrasi. Walaupun ini masih dipertanyakan dalam dunia akademik, konsep ini berimplikasi mengandung isu strategis dari berbagai aspek kehidupan dalam skala yang tidak lagi terbatas oleh batas-batas geografis. Sebagai akibatnya, fenomena global village ini menuntut antisipasi negara dan masyarakat yang harus bekerjasama dengan negara dan masyarakat bangsa lain karena baik global village maupun globalisasi telah menyatukan masyarakat dari berbagai kawasan dunia menjadi satu komunitas global.

\footnotetext{
${ }^{1}$ FGD tim GV dengan Mayling Oey Gardiner di Jakarta pada 12 April 2014.
} 
Sebagaimana telah dijelaskan oleh McLuhan global village dapat dilihat sebagai hilangnya batas-batas wilayah dan kemasyarakatan akibat perkembangan teknologi komunikasi dan telekomunikasi yang semakin canggih. Potret lain dari global village adalah terciptanya suatu kehidupan masyarakat yang semakin menyatu dengan pola hubungan yang semakin terikat satu dengan yang lain. Dengan demikian, global village tidak lain dapat didefinisikan sebagai suatu tatanan kehidupan baru yang mengabaikan batas-batas geografis, ekonomi, politik, dan budaya masyarakat (borderless world), dan menekankan pada arus informasi dalam suatu jalinan komunikasi dan komparasi.

Hasil FGD menunjukkan bahwa fenomena global village dilihat dalam perspektif yang lebih positif sebagai ruang dan kesempatan untuk memungkinkan dan mendorong terjadinya proses pertukaran kebudayaan sekaligus mempromosikan toleransi dan keberagaman. Dengan demikian, secara konseptual, global village sebagai fenomena sosial mengandung dimensi multikultural yaitu terjadinya pertukaran ide-ide yang berlangsung secara bebas. Pada sisi lain, hilangnya batasbatas sosial antarkelompok masyarakat akan memunculkan proses interaksi antar-anggota masyarakat yang semakin kompleks. Kondisi ini berpotensi melahirkan konflik dan krisis sosial. Lingkungan sosial terjadinya ruang global village, dalam konteks identitas kebudayaan, dapat dilihat tempat dimana berbagai budaya bertemu dan berakulturasi bahkan berasimilasi satu sama lain. Budaya yang kuat, seperti American pop culture, akan mendominasi dunia dengan kekuatan media, dalam kondisi ini, sejumlah nilai dan norma tradisional yang dianut masyarakat akan mengalami degradasi dan terancam oleh kultur ini.

Pandangan tentang global village juga diungkapkan oleh Yulfita Raharjo, Pakar Kependudukan LIPI, yang mengatakan bahwa global village menggambarkan dunia kita sebagai rumah dari semua bangsa dimana penghuninya dengan mudah saling berhubungan dan berkomunikasi termasuk dalam mengakses informasi, bertransaksi; melalui proses globalisasi yang berjalan cepat. ${ }^{2}$ Salah satu implikasi dari fenomena global village adalah penduduk dunia dalam proses sosial yang semakin 'didekatkan' melalui perkembangan teknologi; perdagangan; investasi; perjalanan; budaya populer; kesepakatankesepakatan global; dan bentuk-bentuk interaksi yang lain sehingga batas-batas suatu negara menjadi semakin sempit pada satu sisi dan semakin terkait dan terikat pada sisi yang lain. Akibat lain dari fenomena global village adalah bahwa manusia bisa berhubungan ke hampir penjuru dunia hampir-hampir tanpa biaya. Kecanggihan teknologi (misalnya dalam bentuk mobile phone; internet, computer)

\footnotetext{
${ }^{2}$ Disampaikan oleh Yulfita Raharjo dalam FGD di Jakarta pada 2014
} 
"mendekatkan" kita tanpa jarak (waktu dan tempat). Kondisi tersebut dapat digambarkan dalam suatu abstraksi ilmiah bahwa dunia tempat kita hidup rasanya menjadi 'menciut'; layaknya hidup dalam sebuah desa (global).

Yulfita memberikan contoh implikasi dari global village yang dapat dilihat dalam kehidupan masyarakat sehari-hari sebagai berikut. Misalnya, kegiatan belajar yang dilakukan melalui internet atau belajar jarak jauh (e-learning) membuat global village ini menjadi ruang kelas yang mendekatkan' murid dan pengajarnya termasuk materi yang diajarkan, dimanapun mereka berada. Dengan demikian, ia pada sampai pada suatu kesimpulan bahwa konektivitas antar-manusia di dunia telah ikut menyelamatkan kehidupan manusia secara keseluruhan. Selain itu, kecepatan akses informasi telah ikut menyumbangkan dalam upaya menurunkan kematian balita di seluruh dunia dalam arti memungkinkan bayi-bayi di seluruh dunia divaksinasi (difteri, batuk rejan, tetanus). Keterbukaan akses informasi seperti ini juga dapat menurunkan tingkat kelahiran dengan tersosialisasinya dan ketersediaan berbagai alat kontrasepsi. Contoh lain dari fenomena global village adalah pola migrasi penduduk, tidak hanya sekedar dari perdesaan ke perkotaan namun dapat berlangsung dari perdesaan ke kota metropolitan dunia.

Pada sisi lain dunia yang penduduknya memiliki "kedekatan' dan 'menciutnya masyarakat dunia' kedalam Global village tetap membawa implikasi negatif seperti berikut ini. Pertama, wabah penyakit mortalitas bisa cepat menyebar melintas benua hanya karena seorang turis membawa penyakit yang diderita dari negaranya melalui sebuah kapal terbang. Contoh lain adalah dampak domino dari globalisasi termasuk bersatunya dunia dalam ekonomi global membuat krisis ekonomi di negara tertentu dengan mudah tersebar ke negara-negara lain.

Jika ditelusuri lebih jauh, baik proses globalisasi maupun fenomena global village sebagai konsekuensi logis dari globaliasi telah menghubungkan tatanan ekonomi, sosial, budaya dan politik dunia membentuk suatu tatanan dunia baru menyebar ke seluruh penjuru dunia dan merasuk ke dalam kehidupan dan kesadaran warga dunia. Dalam dimensi budaya, global village memiliki kecenderungan mengubah aspek penting kehidupan manusia secara bertahap terutama dalam hal gaya hidup, orientasi budaya, dan kesadaran berbudaya. Namun, kedua proses ini bukan merupakan suatu fenomena yang bersifat terberi (taken for granted), tidak berada di dalam ruang hampa, dan tidak memiliki dampak dan implikasi yang sama terhadap negaranegara dan kelompok-kelompok masyarakat dunia. Sejumlah negara diuntungkan dari globalisasi, dan sejumlah negara dirugikan atau menjadi korban eksploitasi dari globalisasi. Negara-negara atau 
korporasi yang kuat secara alamiah akan mengontrol dan mendominasi sistem ekonomi dan politik dunia yang pada akhirnya akan menentukan nilai budaya global yang diijinkan untuk berkembang dalam global village. Situasi ini digambarkan oleh Frank (1966) sebagai hubungan ketergantungan antara negara-negara satelit, yakni negara yang sedang berkembang, dengan negara-negara metropolis, yaitu negara-negara maju di Eropa Barat dan Amerika Utara. Wallerstein dalam teori sistem dunia menggambarkan sebagai hubungan antara negara-negara pusat (core) dengan negara-negara pinggiran (peripheri).

Globalisasi dan global village, dengan demikian, sangat rentan memunculkan konflik antarnegara dan antar kelompok masyarakat warga dunia karena ada dominasi dari negara atau kelompok masyarakat yang lebih maju dan memiliki akses ekonomi, sosial politik, militer, teknologi dan pengetahuan serta sumberdaya manusia. Globalisasi sebagai sebuah proses sosial yang hidup dalam masyarakat sesungguhnya bukan fenomena yang baru tetapi sudah muncul sebelum masa kolonial. Menurut studi Hanley (1996), globalisasi di kepulauan Indonesia dalam makna ekonomi politik perdagangan telah berkembang jauh sebelum masa masa kolonial pada masa perdagangan cengkeh dan pala. Studi Widjojo (2007) menujukkan pada akhir abad ke-16, Portugis dan Belanda memperebutkan monopoli perdagangan cengkeh di Maluku. Bahkan, pada 1621, seluruh penduduk di Kepulauan Banda dimusnahkan oleh VOC untuk menguasai perdagangan rempah-rempah di kawasan tersebut (Bartels 1978, Ricklefs 1981). Namun perbedaannya, globalisasi pada masa kini telah menciptakan kesenjangan antarnegara dan memunculkan konflik internal dalam setiap negara serta berlangsung sangat cepat dalam sejarah kehidupan manusia. Dengan demikian, baik proses globalisasi dan fenomena global village yang muncul pada masa kini harus dikaji kembali untuk menentukan pola relasi antarnegara dan antarkelompok warga dunia yang setara, adil, dan bermartabat.

\section{Simpulan}

Berdasarkan atas paparan di muka, konsep global village yang relevan digunakan untuk melihat globalisasi pada masa kini berbeda dengan konsep global village yang disampaikan oleh McLuhan. Konsep awal global village adalah abstraksi ilmiah McLuhan untuk menjelaskan fenomena saling keterkaitan antarwarga dunia dalam satu ruang global sebagai akibat adanya perkembangan teknologi informasi, media, dan komunikasi yang sangat pesat. Global village dapat didefinisikan sebagai fenomena globalisasi pada masa kini yang dapat dikenali dari dampaknya yakni semakin memudarnya batas-batas identitas nasional, semakin hilangnya budaya dan identitas lokal, semakin terancamnya 
ekonomi nasional di tengah-tengah ekspansi kapital, dan semakin meningkatnya migrasi internasional. Dengan kata lain, global village merupakan sebagai suatu tatanan kehidupan baru yang mengabaikan batas-batas geografis, ekonomi, politik, dan budaya masyarakat, dan menekankan pada arus informasi dalam suatu jalinan komunikasi dan komparasi.

Implikasi praktis dari studi ini adalah melihat global village dalam konteks Indonesia. Jika ditelusuri lebih jauh, global village dapat membuka potensi untuk menjadi ruang terjadinya tiga proses sosial yang dapat berlangsung secara simultan. Pertama, fenomena ini dapat menjadi sarana dalam memperkenalkan budaya dan identitas lokal. Kedua, secara ekonomi, global village juga mengancam ekonomi nasional di tengah kapitalisme global. Negara yang kuat secara ekonomi akan mudah mengontrol negara yang lemah. Meskipun demikian, global village juga menawarkan janji-janji terciptanya kesejahteraan melalui peningkatan ekspor. Ketiga, secara kependudukan, global village dapat menghilangkan model pembangunan yang berpusat pada geografis dan berpotensi meningkatkan kemampuan SDM. Dengan demikian, topik penelitian yang perlu dikembangkan ke depan adalah bagaimanakah kesiapan masyarakat Indonesia secara sosial budaya dan sosial ekonomi untuk merespon fenomena global village.

\section{Daftar Pustaka}

\section{Buku dan Artikel dalam Buku}

Alter, Adam L., dan Virginia S.Y. Kwan, 2009. "Cultural Sharing In A Global village: Evidence For Extracultural Cognition In European Americans." Journal of Personality and Social Psychology, 96 (4): 742.

Appadurai, Arjun, 2006. "The Right To Research." Globalisation, Societies and Education, 4 (2), 167-177.

Bartels, D., 1978. Guarding The Invisible Mountain: Intervillage Alliances, Religious Syncret-Ism And Ethnic Identity Among Ambonese Christians And Moslems In The Moluccas. Disertasi Doktoral. Cornell University. Ann Arbor Michigan: University Microfilms Inter-national.

Chrystall, Andrew B., 2011. "After the Global village." Canadian Journal of Media Studies 9.

Dery, Mark, 1995. "McLuhan Through the Rearview Mirror." Educom Review (Nov/Dec) 30 (6): 22-29.

Fawcett, Brian, 2004. "What McLuhan Got Wrong About the Global village and Some Things He Didn't Forsee.” Dalam John Moss and Linda M. Morra (eds.), Speed of Light There is Only Illumination: A 
Reappraisal of Marshall McLuhan. Ottawa: University of Ottawa Press.

Frank, A. G., 1966. The Development of Underdevelopment. Boston, MA: New England Free Press.

Henley, David, 1996. Nationalism And Regionalism In A Colonial Context: Minahasa In The Dutch East Indies. Leiden: KITLV Press.

Huyssen, Andreas, 1995. Twilight Memories: Marking Time in a Culture of Amnesia. New York: Routledge.

Jackson, Ronald L dan Micahel A. Hogg, 2010. Encyclopedia of Identity. Thousand Oaks, CA: Sage Publication.

McLuhan, Marshall, 1962. The Gutenberg Galaxy: The Making of Typographic Man. Toronto: University of Toronto Press.

McLuhan, Marshall, 1994. Understanding Media: The Extensions of Man. MIT press.

Parsons, Talcott, 1967. "Durkheim's Contribution To The Theory Of Integration Of Social Systems." Sociological Theory and Modern Society: 3-34.

Ricklefs, M.C., 1981. A History of Modern Indonesia. London: Mcmillan.

Schaeffer, Robert. K, 2003. "Globalization and Technology." Phi Kappa Phi Forum 83 (4): 30-33.

Tredinnick, Luke, 2008. Digital Information Culture: The Individual and Society in the Digital Age. Oxford: Chandos.

Walkosz, Barbara J., et al., 2008. "Global/local: Media literacy for the global village."Paper Submitted for International Media Literacy Research Forum Inaugural Meeting, Ofcom, London.

Wallerstein. W., 1976. The Modern World-System: Capitalist Agriculture and the Origins of the European World-Economy in the Sixteenth Century. New York: Academic Press.

Widjojo, M.S., 2007. Cross-cultural alliance-making and local resistance in Maluku during the revolt of Prince Nuku, c. 1780-181o. Disertasi Doktoral. University of Leiden. 